The Problem of Critical Ontology 
This page intentionally left blank 


\section{The Problem of Critical Ontology}

\section{Bhaskar Contra Kant}

Dustin McWherter

Lecturer, American University of Beirut 


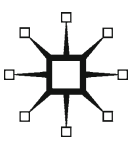

(c) Dustin McWherter 2013

Softcover reprint of the hardcover 1st edition 2013 978-1-137-00271-6

All rights reserved. No reproduction, copy or transmission of this publication may be made without written permission.

No portion of this publication may be reproduced, copied or transmitted save with written permission or in accordance with the provisions of the Copyright, Designs and Patents Act 1988, or under the terms of any licence permitting limited copying issued by the Copyright Licensing Agency, Saffron House, 6-10 Kirby Street, London EC1N 8TS.

Any person who does any unauthorized act in relation to this publication may be liable to criminal prosecution and civil claims for damages.

The author has asserted his right to be identified as the author of this work in accordance with the Copyright, Designs and Patents Act 1988.

First published 2013 by

PALGRAVE MACMILLAN

Palgrave Macmillan in the UK is an imprint of Macmillan Publishers Limited, registered in England, company number 785998, of Houndmills, Basingstoke, Hampshire RG21 6XS.

Palgrave Macmillan in the US is a division of St Martin's Press LLC, 175 Fifth Avenue, New York, NY 10010.

Palgrave Macmillan is the global academic imprint of the above companies and has companies and representatives throughout the world.

Palgrave ${ }^{\circledR}$ and Macmillan ${ }^{\circledR}$ are registered trademarks in the United States, the United Kingdom, Europe and other countries

ISBN 978-1-349-43393-3

ISBN 978-1-137-00272-3 (eBook)

DOI $10.1057 / 9781137002723$

This book is printed on paper suitable for recycling and made from fully managed and sustained forest sources. Logging, pulping and manufacturing processes are expected to conform to the environmental regulations of the country of origin.

A catalogue record for this book is available from the British Library.

A catalog record for this book is available from the Library of Congress.

$\begin{array}{lllllllllll}10 & 9 & 8 & 7 & 6 & 5 & 4 & 3 & 2 & 1\end{array}$

$\begin{array}{llllllllll}22 & 21 & 20 & 19 & 18 & 17 & 16 & 15 & 14 & 13\end{array}$ 
To Lisa, my mother 
This page intentionally left blank 


\section{Contents}

Acknowledgments ix

Note on Abbreviations and Citations $\quad \mathrm{x}$

$\begin{array}{ll}\text { Introduction } & 1\end{array}$

1 Ontology and Critical Philosophy 6

2 Ontology and Empirical Realism 21

2.1 The aetiology of empirical realism in
Hume and Kant

2.2 Bhaskar's general argument for the inexorability
of ontology

3 Transcendental Idealism and Ontological Agnosticism 45

3.1 Transcendental idealism and ontology 46

3.2 Ontological agnosticism and the problem of the thing in itself $\quad 49$

3.3 The problem of Allison's two-aspect view 57

3.4 Ontological agnosticism without things
in themselves

4 Kant's Conception of Natural Necessity 67

4.1 Natural necessity and categorial synthesis 68

4.2 Natural necessity and constant conjunctions 79

5 Bhaskar's Transcendental Analysis of

Experimental Activity $\quad 86$

5.1 The presuppositions 86

$\begin{array}{ll}5.2 \text { The arguments } & 91\end{array}$

5.3 Conclusion 113

6 Natural Necessity and the Transcendentally Real 116

6.1 Kantian causal laws and open systems 117

6.2 Normic statements and natural necessity 126

6.3 Cognitive experience and a category of being 133 
viii Contents

Conclusion

Notes

Bibliography 178

Index 183 


\section{Acknowledgments}

I would like to thank the Centre for Research in Modern European Philosophy (then at Middlesex University, now at Kingston University) in London for granting me a research studentship, without which my doctoral study and thesis, upon which this book is based, would not have been possible. I would also like to thank those who provided me with very helpful feedback on my work in either a professional or informal capacity. These include Ray Brassier, Peter Hallward, Christian Kerslake, Robin Mackay, Christopher Norris, Peter Osborne, and Stella Sandford. Finally, I would like to thank my family and friends for their support and confidence in me over the last several years. I should note that an earlier version of Chapter 3 appeared as 'Transcendental Idealism and Ontological Agnosticism' in Kantian Review Vol. 17, No. 1 (2012), pp. 47-73 and an earlier version of Chapter 5 appeared as 'Reconstructing Bhaskar's Transcendental Analysis of Experimental Activity' in Cosmos and History: The Journal of Natural and Social Philosophy Vol. 8, No. 1 (2012), pp. 199-226. 


\section{Note on Abbreviations and Citations}

For the sake of convenience, I have used abbreviations of works by Kant and Bhaskar. These are listed below, and in the bibliography these abbreviations are given in parentheses after the date of the work.

Works by Bhaskar:

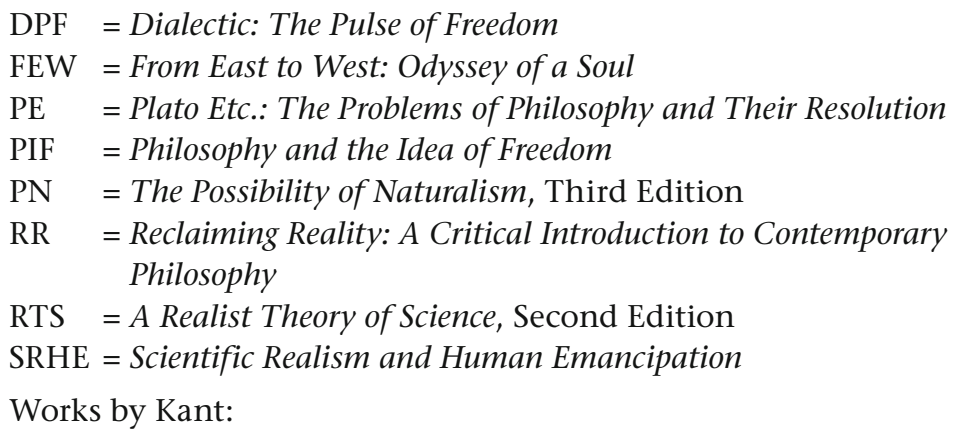

LH = 'Fourth Letter: From Kant to Herz, February 21, 1772'

$\mathrm{LM}=$ Lectures on Metaphysics

$\mathrm{P} \quad=$ Prolegomena to any Future Metaphysics: With Selections from the Critique of Pure Reason

TP1 = Theoretical Philosophy, 1755-1770

I have also cited works using pagination from a more original edition that is given in the margins of the work. Thus page numbers for the Critique of Pure Reason are in the standard 'An/Bn' format (and all passages are from the Guyer/Wood translation unless noted otherwise), page numbers for the Prolegomena are in accordance with the Academy Edition of Kant's works, page numbers for Aristotle are in accordance with Immanuel Bekker's standard 1831 edition of the Greek text (and no citations from Aristotle include a year), page numbers for Hume 1748 are in accordance with the 1777 edition of that work, and page numbers for Heidegger 1927 are in accordance with the German pagination of that work. There are also works that are cited using section (' $\$$ ') numbers instead of page numbers. These are: Wolff 1720, Baumgarten 1739, and Hegel 1807. Furthermore, there are older works that I have 
chosen to cite using the year of the original date of publication rather than the date of more recent editions. For example, I use 'Hume 1748' to refer to the Enquiry concerning Human Understanding, although the actual edition I use (and listed in the bibliography) is the 1975 edition of the two Enquiries published by Oxford. In cases of such discrepancy I have given, in the bibliography, the year I use in citing the work in parentheses after the year of the more recent edition. I have also used some sources that, because they are published online, are cited in the text without page numbers. These are Bhaskar/Norris 1999, Corazzon 2010, and Thomasson 2009. Finally, Bhaskar/Callinicos 2003 and Bhaskar/ Laclau 1998 are published transcripts of live debates between those listed as the authors. When citing passages from these works, I have placed the initial of one of the authors before the page number to indicate that the passage cited is from a part of the debate where that author is speaking. For example, a passage from Bhaskar in Bhaskar/Callinicos 2003 would be cited as 'Bhaskar/Callinicos 2003: B98'. 